\title{
ジベレリンの新しいイネ苗テスト“点滴法”および そのイネ，アサガオ抽出物への適用
}

\author{
村上浩* \\ Yutaka Murakami*: A New Rice Seedling Test for Gibberellins, 'Microdrop Method', \\ and its Use for Testing Extracts of Rice and Morning Glory.
}

Received September 20, 1967

\begin{abstract}
A new bioassay is described which is based upon the elongation response of the second leaf sheath of rice plants to gibberellins. Rice seedlings, at their first leaf stage, were treated by applying gibberellins to coleoptils in a $1 \mathrm{ul}$ drop of 50\% acetone using a micropipette. Agar blocks can be used in place of test solution.

By means of this method, five cultivars of rice, including one normal and four dwarfs of different simple recessives, were tested for their response to gibberellins $A_{1}$ to $A_{5}$. Gibberellins $A_{1}$ and $A_{3}$ are of high potency in these cultivars. The dwarfs differ in the specificity of their response to gibberellins. For example, 'Tan-ginbozu' responses well but 'Waito-C' much less to Gibberellin $A_{5}$. These dwarfs can be used as a 'mutiple plant assay' to detect gibberellins with similar structures. Gibberellin $A_{3}$ can be bioassayed in the range from 0.05 up to $100 \mathrm{~m} u \mathrm{~g}$ using the 'Tan-ginbozu' dwarf.

The rice test using microdrop application was less susceptible to inhibiting substances such as Abscisin II, fusarinic acid, and indoleacetic acid than the test using the application in growing media. Because of this and because of the rapidity and high sensitivity of the test, it has been successfully applied to the estimation of gibberellin-like substances in extracts from small quantities of rice shoots and Pharbitis nil seeds.

The chromatographic behavior of the active zone of rice shoot material was similar to that of gibberellin $\mathrm{A}_{3}$. Bioassays on extracts of Pharbitis nil seeds using the 'Tan-ginbozu' and 'Waito-C' dwarfs indicated the presence of gibberellin-like substances with differential effects on the two dwarfs.
\end{abstract}

ジベレリンのバイオアッセイのために著者が考案 したイネ苗テスト1)は, 操作が簡単であり, 測定值 の偏差が少い。しかし，この方法は，発芽させた粐 を試験液に浸すために, 精製していない植物抽出物 や有機溶媒を含む試験液では, 共存する阻害物や有 機溶媒のために，発芽粐が枯死する場合がある。ま た，与えたジベレリン量と伸長との関係を, 植物 1 株 当りとして正確に表現することが困難である。そこ

*農林省農業技術研究所 National Institute of Agricultural Sciences, Kita-ku, Tokyo, Japan.
で，著者は，ジベレリンのエンドウテスト2)やトウ モロコシテスト3)のように，試験液を葉に与えるイ ネ苗テストを試みた。

この新しいイネ苗テスト, 点滴法を用いて, 劣性 の単一遺伝子による矮性イネについて, ジベレリン $\mathrm{A}_{1}, \mathrm{~A}_{2}, \mathrm{~A}_{3}, \mathrm{~A}_{4}, \mathrm{~A}_{5}$ の活性を比較した。 また，この 方法による Abscisin II, フザリン酸, インドール 酢酸の葉鞘伸長阻害についても検討した.さらに, イネの葉やアサガオの種子抽出物のジベレリン様物 質の検出, 定量に, この点滴法を適用した結果につ いても報告する。 


\section{材 料と方 法}

\section{I. バイオアッセイ}

比重 1.05 の食塩水で塩水選した粐を，0.1\% ウス プルン液に 30 分〜1 時間浸して殺菌した後，2 日間 $32^{\circ}$ の水に浸して拉くと, 子葉䩗が現れてくる.内径 $2.8 \mathrm{~cm}$, 高さ $6 \mathrm{~cm}$ の管びえに, $1 \%$ 寒天を $5 \mathrm{~cm} \mathrm{の}$ 高さまで加えておく. 子葉鞘の長さが $2 \mathrm{~mm}$ になっ た粀を選び，寒天の上に 1 びん当り 5 こずつ，子葉 鞘を上にして植える. これを 5,000-7,000ルックス の溃光灯で連続照射している $32^{\circ}$ に保った植物生育 箱に入れ， 45 時間後に，第 2 葉の先端が第 1 葉か ら $2 \mathrm{~mm}$ 出た状態まで育てる.この状態のイネ苗の 子葉鞘と第 1 葉との間に, マイクロピペットで試験 液 $1 \mu l$ 安与える。被験物は $50 \%$ アセトンに溶かし ておく.

試験液の代りに，オーキシンのアベナ屈曲テスト に使用すると同じような寒天片に，試料を含ませて 与えることも出来る。まず， $1.5 \%$ の察天液に同量 の試料の水溶液を加え, よく混合させる. スライド ガラスを $60^{\circ}$ 前後に温めてから，水平板の上におく。

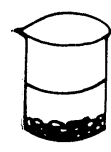

\section{GERMINATE}

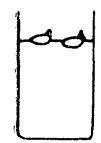

PLANT ON AGAR

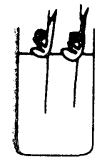

APPLY TEST SOLUTION OR AGAR BLOCK
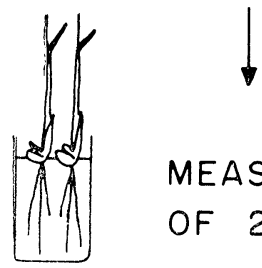

\section{MEASURE LENGTH OF 2ND LEAF SHEATH}

Fig. 1. Procedure of the new rice seedling test (microdrop method). $60^{\circ}$ 前後に温めて拈いたメスピペットで溶けている 寒天液の一定量を，スライドガラスにピペットを斜 めに傾けて，周囲から流しはじめて中央部に至る方 法で,ガラスの表面を寒天液で扣扔う。この寒天ゲル の厚さを $1.5 \mathrm{~mm}$ にするために, 用いたスライドガ ラスの表面積から寒天液の使用量を決定する．寒天 が固まってから，スライドガラスを方眼紙の上にお き, 安全カミソリの刃で $2 \times 2 \mathrm{~mm}$ の問隔で縦横に 切って, $1.5 \times 2 \times 2 \mathrm{~mm}$ の寒天片をつくる.

使用したイネ(Oryza sativa) の品種は，正常種 の曟林 25 (Norin 25), 矮性イネの短銀坊主（Tanginbozu), 小丈王錦 (Kotake-tamanishiki), 矮稲一 C (Waito-C), 紫大黑 (Murasaki-daikoku) であ る.これらの矮性イネは, いずれも, 異なる単一劣 性遺伝子によって草丈が矮性化したものである ${ }^{4,5)}$.

この点滴法によるイネ苗テストを簡単に第 1 図に 示した。

\section{II. バイオアッセイに附した物質}

\section{1. 既知化合物}

ジベレリン $A_{1}, A_{2}, A_{3}, A_{4}\left(G_{1}, G_{2}, G A_{3}\right.$, $\mathrm{GA}_{4}$ と略する)：1960年頃に，当時の東京大学農 学部，住木諭介教授よりいただいた。

ジベレリン $A_{5}\left(\mathrm{GA}_{5}\right.$ と略する）：東京大学農学 部，高橋信孝博士よりいただいた。

Abscisin II (Ab II と略する)：京都大学農学 部，小清水弘一博士よりいただいた.

フザリン酸： 1955 年頃に，現在の山梨大学工学 部，林武教授よりいただいた。

インドール酢酸 (IAA と略する)：東宗化成工業 株式会社から䝼入した.

\section{2. 植物抽出物}

イネ(品種, 農林 8 号) の苗：苗代で約 1 ケ月生 育させ，草丈 $28 \mathrm{~cm}$ になった苗 24 本の地上部（生 体重は20g）学 $200 \mathrm{ml}$ の $70 \%$ アトンにて磨砕し。 1 日攪汼する。布でしぼり，残りはもら一度 $70 \%$ アセトンで抽出する。両抽出物をる紙でこした後， 減王で源縮してアせトン定除く、残留液をリン酸で pH 2.5 として，1/3 量の酰酸エチルで 3 回抽出す る。酢酸エチル層を $1 / 3$ 量の $1 \mathrm{~N}$ のリン酸緩衝液 （pH 7）で 3 回抽出し，この緩衝液を再びリン酸で $\mathrm{pH} 2.5$ とした後，䣷酸エチルで 3 回抽出する. 得 られた酢酸エチルを無水硫酸ソーダで脱水した後, 
減压で浱縮してえた抽出物を，酸性酢酸エチル分画 とし，薄層クロマトグラフィーに附した.

アサガオ (Pharbitis nil) の未熟種子：アサガオ の成熟後期でまだ緑色の果実を真空凍結乾燥し，傽 岁除いた種子少ら，イネの苗と同じように，含水ア 七トンによる抽出物をつくる、これを炭酸ソーダで $\mathrm{pH} 8.0$ とし, 䣷酸エチルで 2 回抽出した後, 水層 の方帘りン酸で $\mathrm{pH} 2.5$ とする. この水層它クロロ ホルムで 3 回抽出し, 酸性のク口ロホルム分画とす る.この裖縮物を、イソプロパノール：アンモニア： 水 $(10: 1: 1)$ の混液でペーパークロマトグラフィー を括こなって得た $R_{F} 0.6$ 附近の活性物質（即占，前 報6)第 7 図のNo. 9 の分画に相当する) 老, 薄層ク口 マトグラフィーに附した。

\section{3. 薄層クロマトグラフィー (TLC)}

$20 \times 20 \mathrm{~cm}$ のガラスプレートに $0.25 \mathrm{~mm}$ の厚さ の Silica Gel G の薄層をつくり, 上昇法で $10 \mathrm{~cm}$ 展開した。展開剤としては,イソプロピルエーテル： 水䣷酸 $(95: 5)$ の混液7が使用された.

展開の終ったプレートの原点から，展開方向に 1 $\mathrm{cm}$ の間隔（イネ抽出物の場合には，第 1 番目の夕 $0.5 \mathrm{~cm}$ の間隔で二分した）で，シリカゲルをかき 取り，吸着物を50\%アセトンで小ビーカー中に溶 出した。溶出物にへヤドライヤーで熱風を送り, 乾 燥させた後, $50 \mu l$ の $50 \%$ アセトン液を加えて, 再 び溶出物を溶かす．この溶液 $1 \mu l$ を 1 本のイネ苗に 与えて，上述の新しいイネ苗テストに附した。

$\mathrm{GA}_{3}$ および $\mathrm{GA}_{5}$ のクロマトグラム上の位置は, エタノール：濃硫酸 $(95: 5)$ の混液を櫴霧し， $120^{\circ}$ に 10 分間熱した後に現れる紫外線下の螢光により 定めた。

\section{結果 と考 察}

\section{I. $\mathbf{G A}_{3}$ の活性}

第 1 表に，点滴法によってイネ苗テストを実施し た場合の，正常種および矮性種の第 2 葉鞘の伸長と $\mathrm{GA}_{3}$ の䟴度との関係を表にして示した.この实験条 件では，正常種の農林 25 は，植物体当り, $0.5 \mathrm{~m} \mu \mathrm{g}$, 矮性種の短銀坊主, 矮稲 Cでは，0.05 mug, 小丈玉 錦では, $0.1 \mathrm{~m} \mu \mathrm{g}$, 紫大黑では $0.5 \mathrm{~m} \mu \mathrm{g}$ から有意差

Table 1. Response of one normal and four dwarfs of rice to $\mathrm{GA}_{3}$. (Mean length, mm, of 2nd leaf sheath)

\begin{tabular}{lcccccccc}
\multicolumn{1}{c}{ Rice cultivar } & \multicolumn{7}{c}{ GA $_{3}$ (m eg/plant) } \\
& Control & 0.05 & 0.1 & 0.5 & 1 & 5 & 10 & 100 \\
\hline Norin 25 (normal) & 30.9 & 31.5 & 32.8 & 36.0 & 40.6 & 47.6 & 51.6 & 60.5 \\
Tan-ginbozu (dwarf) & 16.4 & 18.2 & 18.8 & 23.8 & 26.4 & 34.8 & 40.4 & 53.6 \\
Kotake-tamanishiki (dwarf) & 19.2 & 20.4 & 21.0 & 25.4 & 27.4 & 37.0 & 43.4 & 53.4 \\
Watio-C (dwarf) & 15.4 & 17.0 & 17.8 & 25.0 & 27.8 & 43.4 & 47.3 & 54.8 \\
Murasaki-daikoku (dwarf) & 17.0 & 17.2 & 17.2 & 21.8 & 23.2 & 27.0 & 31.4 & 36.2
\end{tabular}

The test compound was dissolved in $50 \%$ acetone and a $1 \mu l$ test solution was applied to the coleoptile of five rice seedlings at the first leaf stage. Three days later the lengths of the second leaf sheath were measured and summed for each seedling. The mean was determined for each set of five plants. Assay responses were not regarded as positive unless they were $10 \%$ or greater than over the controls. The same is the case with other tables and figures.

Table 2. Comparison of two methods in the 'Tan-ginbozu' dwarf rice test for gibberellins.

\begin{tabular}{lcrrr}
$\begin{array}{c}\text { Application of } \\
\text { test sol. }\end{array}$ & $\begin{array}{c}\text { Days to complete } \\
\text { prep.+test }\end{array}$ & $\begin{array}{c}\text { Volume }(\mu l) \\
\text { of sol. per } \\
\text { test unit }\end{array}$ & $\begin{array}{c}\text { Sol. concn. } \\
\mu \mathrm{g} / \mathrm{m} l\end{array}$ & $\begin{array}{r}\text { Wt. of GA } \mathrm{GA}_{3} \\
\mu \mathrm{g} / \text { test unit }\end{array}$ \\
\hline $\begin{array}{l}\text { Growing medium } \\
\text { Microdrop }\end{array}$ & $2+5$ & 500 & $0.02-200$ & $0.01-100$ \\
\hline
\end{tabular}


のある伸長促進がみられた.イネには，穀粒の小円 形な大黒型の矮性種が幾つか知られている．従来の 浸漬法によるイネ苗テストでも，これらの矮性種の $\mathrm{GA}_{3}$ に対する感受性はよくない8).

短銀坊主によるイネ苗テストについて, 点滴法と 浸漬法とを比較し, Coombe ら ${ }^{93}$ がジベレリンの種々 なバイオフッセイについてまとめた表にしたがって 作成した結果が，第 2 表である. 二つの方法を比較 すると, 粐を発芽させる時から結果を測定するまで の所要日数は, 両方法とも 7 日である. しかし, 点 滴法を用いると，試験液で処理した後から測定まで の日数は, 約半分でよい，その代りに，試験苗をつ くるのに手間がかかる. 試験単位, 即ち, 浸漬法で は管びえ当り, 点滴法では植物個体当り, の試験液

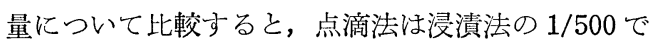
よい。亦た, $\mathrm{GA}_{3}$ の絶対量からみると, 点滴法は 1/200で足り，貴重な試料の試験に適している. 濃 度からみた感度については, 浸漬法は $0.02 \mu \mathrm{g} / \mathrm{m} l$, 点滴法法 $0.05 \mu \mathrm{g} / \mathrm{m} l$ の $\mathrm{GA}_{3}$ から定量できる. し たがって, 希薄な試験液が多量にある場合には, 従
来の浸漬法がすぐれている，また，クロマトグラ フィーを抗てなったならば，点滴法では，ろ紙，シ リカゲルなどの吸着凨から, 溶出, 濃縮の操作を, バイオフッセイに附する前にする必要がある.

\section{II. $\mathbf{G A}_{1}-\mathbf{G A}_{5}$ の活性}

第 2 図から第 6 図までは, イネの正常種および各 矮性種について, $\mathrm{GA}_{1}-\mathrm{GA}_{5}$ の感度曲線を示したも のである.こ机らの図は，イネ第 2 葉䩪の長さの対 数を各ジベレリンの投与量の対数に対してプロット して作成した。

正常種, 矮性種とも, 最もよく反応するジベレリン は $\mathrm{GA}_{1}$ と $\mathrm{GA}_{3}$ である. 各ジベレリンの log-投与量 と $\log$-反応の直線の公配は, 紫大黒を除く各品種で 大きな差がなく, 殆えど直線は平行である.しかし， 小丈玉錦や特に矮稲 Cに拈ける $\mathrm{GA}_{5}$ の勾配が, 他の ジベレリンの勾配に比ベてゅるやかなととが特徵的 である.これらの図から，10 $\mathrm{m} \mu \mathrm{g}$ の投与量に沶け る $\mathrm{GA}_{3}$ の活性を 100 とした場合の比活性を求めて, 第 3 表にまとめてみた。この表でも明らかなように。

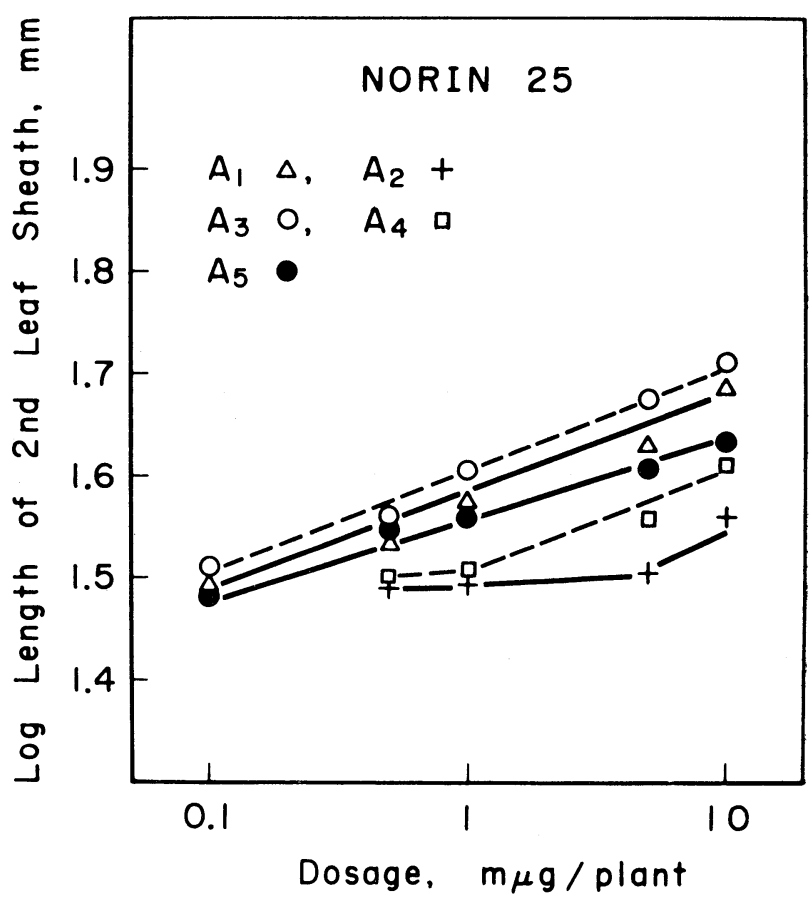

Fig. 2. Potency of gibberellins in the new rice seedling test using Norin 25 . 


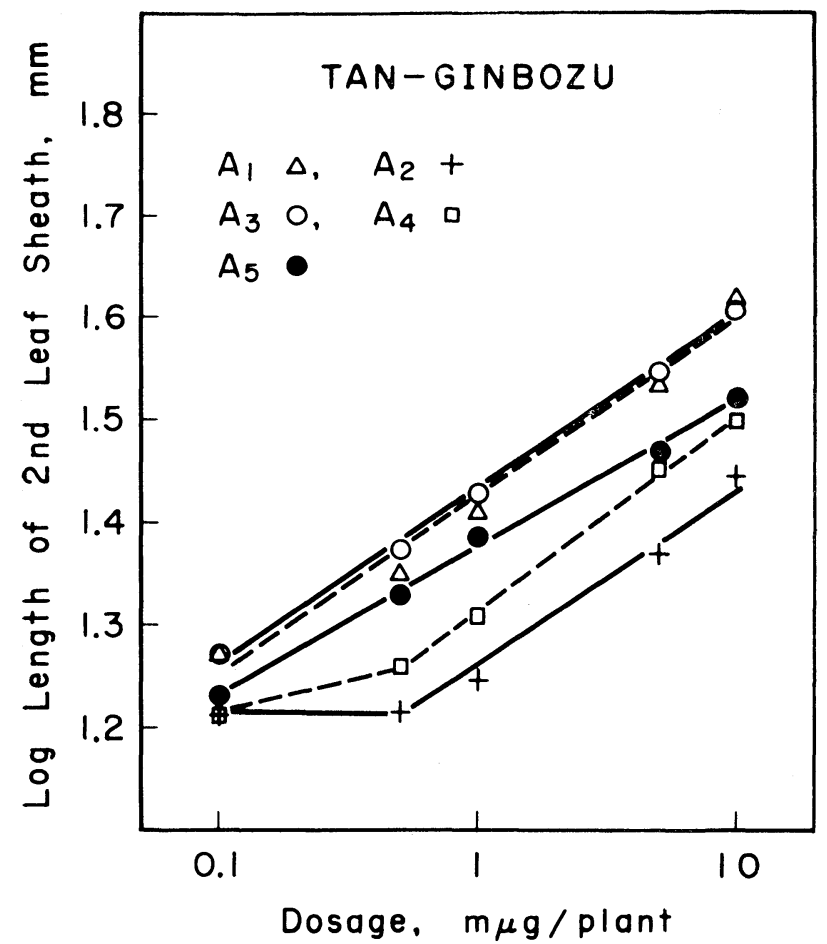

Fig. 3. Potency of gibberellins in the new rice seedling test using Tan-ginbozu.

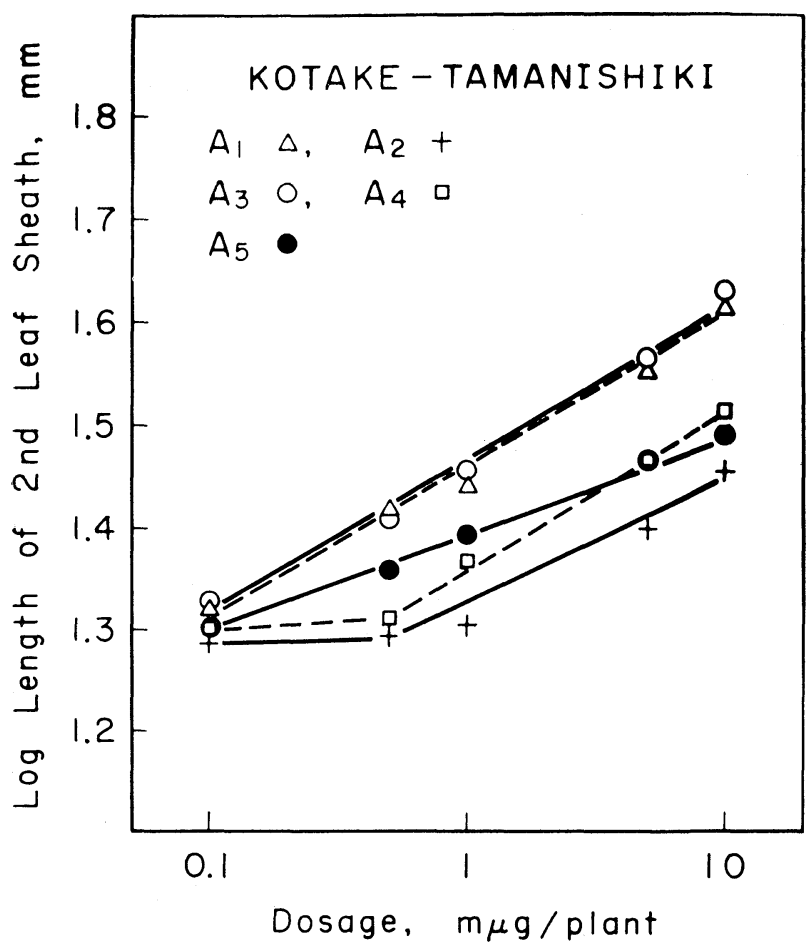

Fig. 4. Potency of gibberellins in the new rice seedling test using Kotake-tamanishiki. 


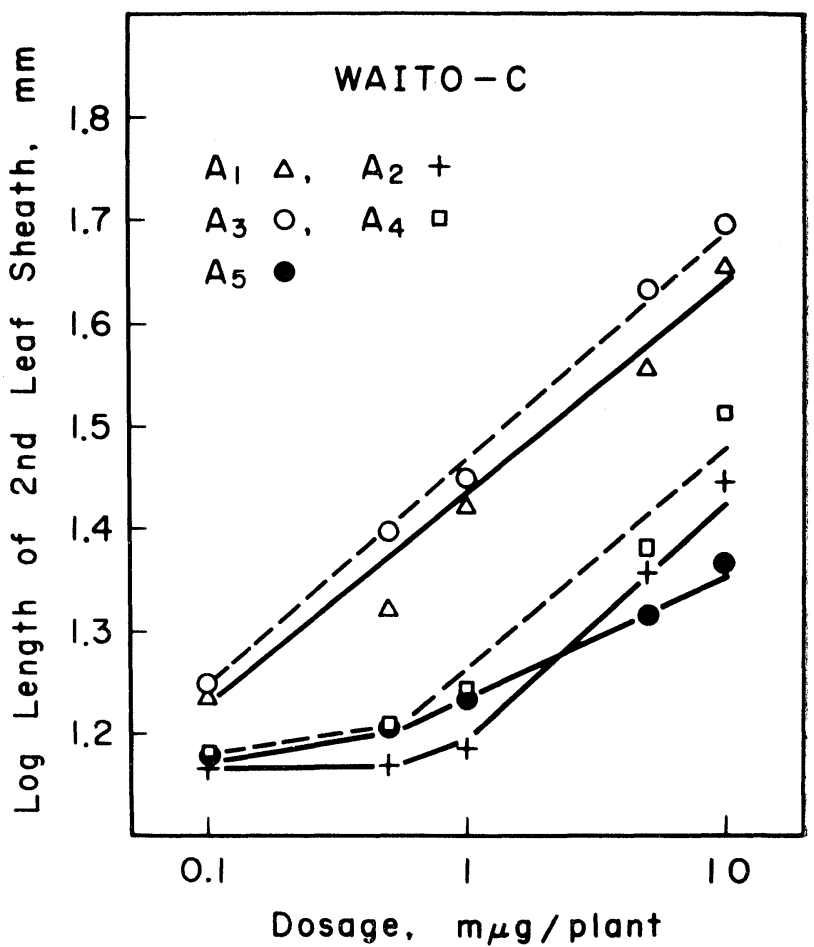

Fig. 5. Potency of gibberellins in the new rice seedling test using Waito-C.

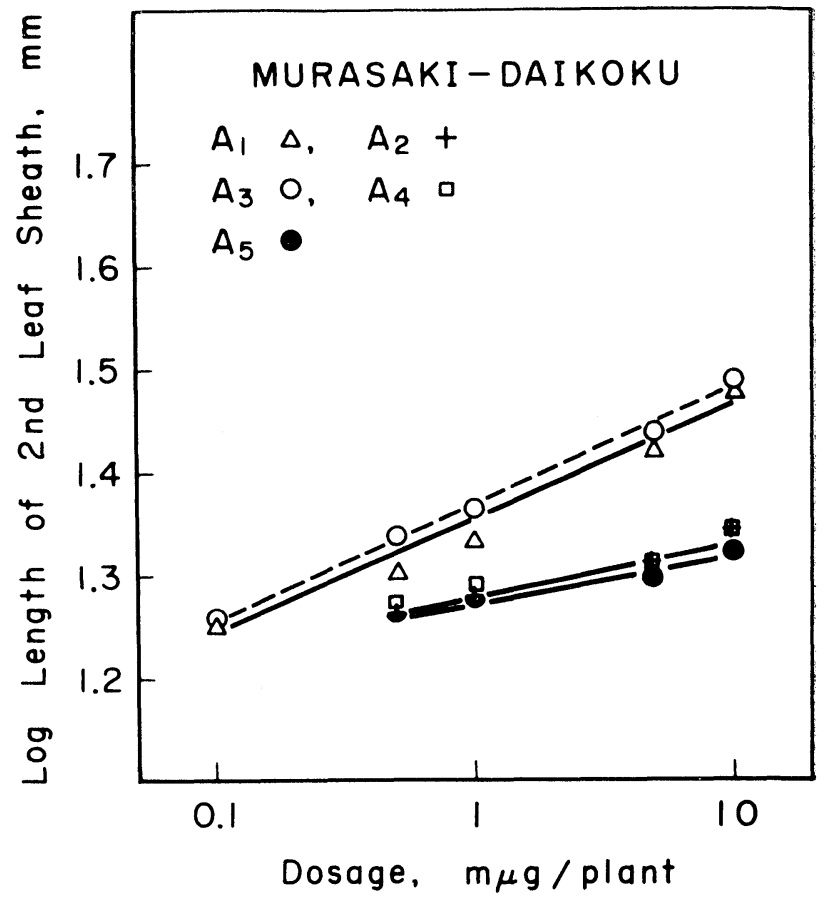

Fig. 6. Potency of gibberallins in the new rice seedling test using Murasaki-daikoku. 
$\mathrm{GA}_{5}$ の比活性が，矮性イネの間でかなり異なってい る. 短銀坊主では, $\mathrm{GA}_{5}$ は $\mathrm{GA}_{3}$ の約 $1 / 3$ の活性觉 もっているが，矮稲 $\mathrm{C}$ や紫大黑では, 1/10１/20 の 弱い活性しかない, また, 小丈王錦では, 両者の中 間で，約 $1 / 5$ の活性である。

このような矮性实然变異体間の各種ジベレリンに 対する感受性の差異は，すでに，トウモロコシの場 合に知られている。例えば，トウモロコシ $d_{1}$ 乫然 变異体では， $\mathrm{GA}_{5}$ の活性が非常に低く, $d_{5}$ 突然变異 体では $\mathrm{GA}_{3}$ と同じく高い10.11). $\mathrm{GA}_{5}$ のトウモロコ シ $d_{1}, d_{5}$ に対するこのような活性の差を利用して, 植物の抽出物中に, $\mathrm{GA}_{5}$ の存在の有無が榉論されて いる12,13,14). ジベレリンの種颣の判定のために， ト ウモロコシの突然変異体を利用すると同じょうに， 短銀坊主と矮稻 Cの同じ試料に対寸る伸長促進の差 を利用することが可能である，その適用例を，後述 するアサガオ未熟種子の抽出物についての実験結果 の項记する.

橋本と八巻 ${ }^{15)}$ によると, 正常種の農林 29 它用い たときのジベレリンの活性は, $\mathrm{GA}_{1} \doteqdot \mathrm{GA}_{3} \gg \mathrm{GA}_{4}>$ $\mathrm{GA}_{2}$ の順序であった。 また, 小川16)は矮性種の小丈 玉錦定使用し, $\mathrm{GA}_{3}>\mathrm{GA}_{1}>\mathrm{GA}_{7}>\mathrm{GA}_{2}>\mathrm{GA}_{5}>$ $\mathrm{GA}_{4}>\mathrm{GA}_{9}>\mathrm{GA}_{8}$ の活性の順序を報告している. $\mathrm{GA}_{2}$ と $\mathrm{GA}_{4}$ の活性について, 両者の間に不一致が みられる. 著者の本実験結果は, 橋本と八巻の結果 に似ており，小川の $\mathrm{GA}_{2}$ の活性が $\mathrm{GA}_{4}$ よりも高い 結果は得られなかった。このような不一致の生ずる 原因の一つとして, 試験した標品の純度をあげねば ならないだろう。

\section{III. 寒天法}

最近，オーキシンのアベナ屈曲テストのように, 茎の先端などから移動してくる所謂“拡散性ジベレ リン”を寒天片に集めることが打こなわれている17)。
多くは，寒天片から再び有機溶媒によって，ジベレ リンを抽出した後，バイオアッセイを実施している。 ただ，Cohen ら ${ }^{18)}$ が, 直接寒天片を矮性エンドウの 茎につけて, 拡散性ジベレリンの定量が可能である ことを報告している。点滴法に使用したイネ苗は, アベナ屈曲テストに用いる子葉鞘と同じ程度の大き さであるから，試駼液の代りに，オーキシン定量用 の寒天片を，イネ苗の子葉鞘と第一葉との間に載せ ることが出来る.

第 7 図は，所定の $\mathrm{GA}_{3}$ を含ませた $6 \mu l(1.5 \times 2 \times$ $2 \mathrm{~mm})$ の $0.75 \%$ の寒天片をイネ苗に与光た場合の 第 2 葉鞘の伸長を示したものである。短銀坊主を試 験植物として選えだ場合には，0.05 $\mathrm{m} \mu \mathrm{g} の \mathrm{GA}_{3}$ を 含えだ寒天片で, 約 $20 \%$ の伸長促進が浔められた. この程度の感度は, オーキシンのアベナ屈曲テスト の感度 ${ }^{19}$ に相当し, 拡散性ジベレリンの測定に利用 できるものとおもう。

\section{Abscisin II，フザリン酸，インドール酢酸の 伸長阻害作用}

小清水ら ${ }^{200}$ は, ルーピンの未熟な莢から Ab II を 単離するためのバイオアッセイとして，浸漬法によ るイネ苗（品種，小丈玉錦）の第 2 葉鞘の伸長阻害 を利用している。第 8 図は, 点滴法のイネ苗テスト における Ab II の葉鞘伸長阻害を示したものである.

農林 25 ，短銀坊主孛用いた場合， $20 \mathrm{~m} \mu \mathrm{g}$ （20 ppm) から伸長阻害が認められ, 伸長定完全に停止 させるには，2 $2 \mu \mathrm{g}(2,000 \mathrm{ppm})$ を必要とした。 小清水ら ${ }^{200}$ による浸漬法での絬果では, 点滴法では 阻害作用のない旅度の $2.5 \mathrm{ppm}$ で伸長が完全に停 止している. 点滴法によるAb II の葉鞘伸長抑制 作用は, 裖度からみると, 浸漬法の約 $1 / 800$ である。

イ六馬鹿苗病菌 (Fusarium moniliforme) の代 謝産物の一つであるフザリン酸は, 浸漬法のイネ苗

Table 3. Potency of gibberellins on different rice dwarfs at the concentration of $10 \mathrm{~m} u \mathrm{~g}$, expressed as percentage of $\mathrm{GA}_{3}$-activity.

\begin{tabular}{cccccc}
\hline Gibberellins & Norin 25 & Tan-ginbozu & Kotake-tamanishiki & Waito-C & Murasaki-daikoku \\
\hline $\mathrm{GA}_{1}$ & 80 & 100 & 100 & 80 & 100 \\
$\mathrm{GA}_{2}$ & 5 & 10 & 10 & 10 & 10 \\
$\mathrm{GA}_{3}$ & 100 & 100 & 100 & 100 & 100 \\
$\mathrm{GA}_{4}$ & 10 & 30 & 20 & 20 & 10 \\
$\mathrm{GA}_{5}$ & 20 & 30 & 20 & 5 & 10
\end{tabular}




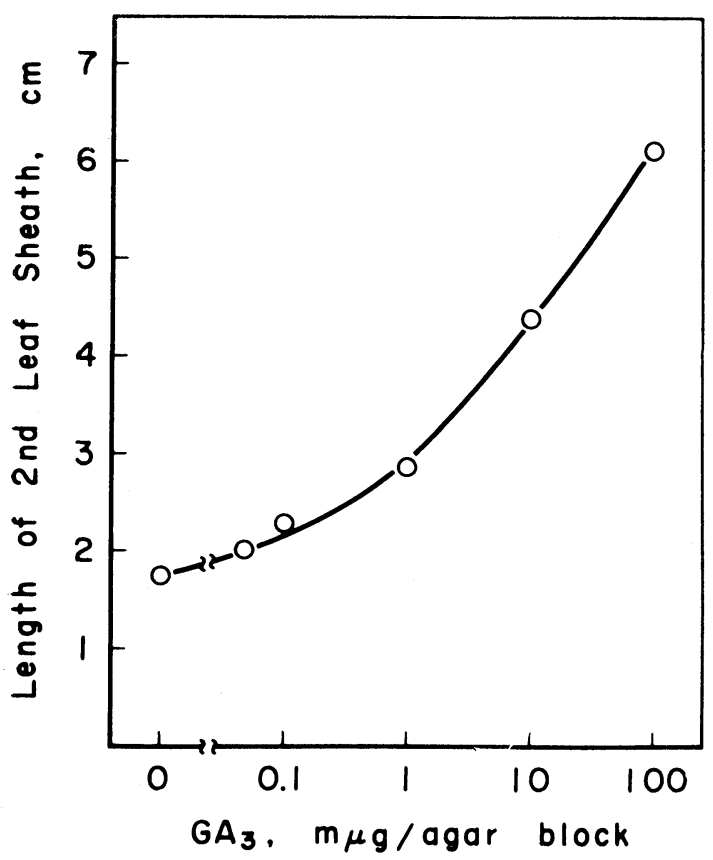

Fig. 7. Elongation of the 'Tan-ginbozu' dwarf rice induced by agar blocks containing $\mathrm{GA}_{3}$. The amount of $\mathrm{GA}_{3}$ was supplied in $1.5 \times 2 \times 2$ $\mathrm{mm}$ agar blocks.

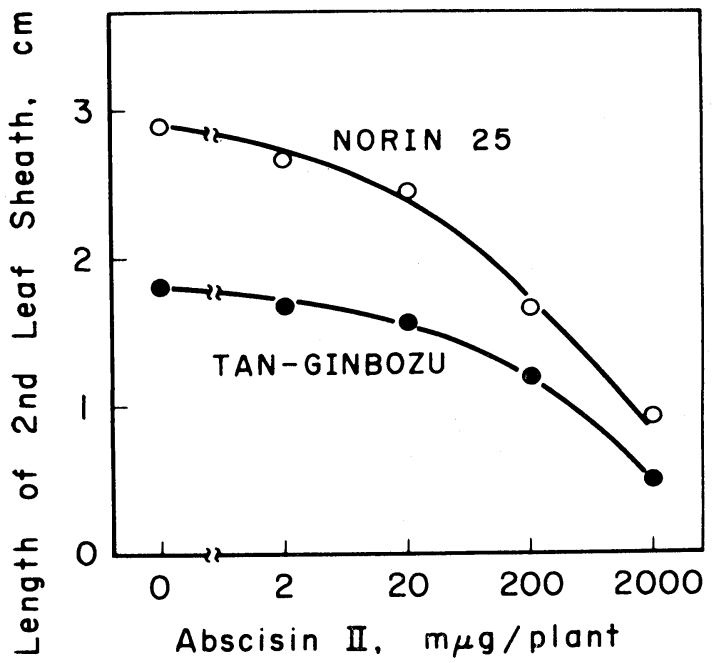

Fig. 8. Inhibitory effect of Abscisin II on the elongation of second leaf sheath of rice seedlings.
テストで， $5 \mathrm{ppm}$ から阻害を示し，100 ppm で殆えど伸長を止めてしまう211。しかるに， 点滴法での結果は，第 4 表のように，1 (1,000 ppm) でわずかに伸長が阻害される 程度である。

イネ葉鞘の切片の伸長生長は, 子葉鞘の場 合と異なり，IAAのようなオーキシンによっ て阻害されることを，著者はすでに指摘し た ${ }^{22)}$. また，浸漬法によるイネ苗テストでも $50 \mathrm{ppm}$ 前後から, 葉鞘の伸長阻害が夕とめ られる8). そこで点滴法によってイネに IAA を与えた場合の影響を実験してみた。その結 果は，第 5 表のようで，葉鞘の伸長阻害がお こるには, $1 \mu \mathrm{g}(1,000 \mathrm{ppm})$ 以上の濃度が 必要であった.

このように，点滴法によるイネ苗テストは， 阻害物質による葉鞘の伸長抑制の程度が, 浸 漬法よりも低く, 植物抽出物中のジベレリン 様物質の検出のためには好都合である.

\section{V. 植物組織の抽出物の結果}

イネの苗条：イネ(品種, 農林 8) の 5 葉 期の苗の酸性酢酸エチル分画をTLCに附し た後，短銀坊主を使用してバイオアッセイを 実施した結果は，第 9 図のようなヒストグラ ムになった。この図で明らかなように， $\mathrm{GA}_{3}$ の移動した位置，No. $2\left(\mathrm{R}_{\mathrm{F}} 0.1 \sim 0.2\right)$ に 活性があらわれた。この活性は， $\mathrm{GA}_{3}$ に換 算すると, 約 $0.5 \mathrm{~m} \mu \mathrm{g}$ に相当する. TLCか らの溶出物を $50 \mu l$ に希勫し，その $1 \mu l$ を 1 本のイネ苗に与えてアッセイをしたわけであ るから，実験に供したイネ苗条，20 g, 24 株 は, 約 $25 \mathrm{~m} \mu \mathrm{g} \mathrm{GA}$ 当量の活性物質を含有し

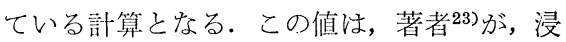
漬法によるイネ苗テストで，イネ地上部のジ ベレリン様物質を測定した值と大体同じで ある。

ヒストグラムの原点に, イネ苗の伸長を阻 害する物質が夕られる。Ab II は，ここに使 用した溶媒系では， $R_{F} 0.6$ 附近に移動した から，原点附近の阻害は AbII によるもの ではない。

アサガオの未熟種子： アサガオの未熟種 
子からのジベレリン様物質をTLCに附した後，シ リカゲルからの溶出物について, 短銀坊主と矮稲 C を用いてバイオアッセイをおこなった。 その結果を 第10図にヒストグラムとして示した.

二つの矮性イネで, No. $2\left(\mathrm{R}_{\mathrm{F}} 0.1 \sim 0.2\right)$ および No. 4〜No. 5 ( $\left.R_{F} 0.3 \sim 0.5\right)$ の 2 筒所に活性があら われた. 前者の活性は, 同時に展開した $\mathrm{GA}_{3}$ の位置 であり, 後者のは $\mathrm{GA}_{5}$ の位置である.上図の短銀坊 主を用いたアッセイの結果では, No. 2 の活性は 2.5 $\mathrm{m} \mu \mathrm{g}$ の $\mathrm{GA}_{3}$ に相当する. しかるに, 下図の矮稲 $\mathrm{C}$ による結果では, $0.05 \mathrm{~m} \mu \mathrm{g} \mathrm{GA}$ 当量であり, 約 $1 / 50$ の弱い活性にすぎない.すでに第 1 表に示したよう に, $\mathrm{GA}_{3}$ は短銀坊主, 矮稲 $\mathrm{C}$ に同程度の伸長反応 を示すことから，No. 2 の活性は， $R_{F}$ は同じでも， $\mathrm{GA}_{3}$ そのものによるのではない.

No. 4〜No. 5 のジベレリン様物質は, $\mathrm{GA}_{5}$ に相 当する $\mathrm{R}_{\mathrm{F}}$ 值である. その活性は，短銀坊主のアッ 七イでは, 約 $100 \mathrm{~m} \mu \mathrm{g} \mathrm{GA}_{5}$ に相当し, 矮稲 $\mathrm{C}$ 用 いた場合にも, 約 $100 \mathrm{~m} \mu \mathrm{g} \mathrm{GA}_{5}$ で，二つのアッセ イで，ほぼ同じ值を示した． $\mathrm{GA}_{3}$ に換算すると， 前者では約 $20 \mathrm{~m} \mu \mathrm{g}$, 後者では約 $2 \mathrm{~m} \mu \mathrm{g}$ である.つ
Table 4. Inhibitory effect of fusarinic acid on the elongation of second leaf sheath of rice Norin 25.

\begin{tabular}{cc}
\hline $\begin{array}{c}\text { Fusarinic acid } \\
\mu \mathrm{g} / \text { plant }\end{array}$ & $\begin{array}{c}\text { Length of } 2 \mathrm{nd} \\
\text { leaf sheath, } \mathrm{mm}\end{array}$ \\
\hline 0 & 29.0 \\
0.01 & 28.8 \\
0.1 & 29.0 \\
1 & 25.2 \\
\hline
\end{tabular}

Table 5. Inhibitory effect of indoleacetic acid on the elonagation of second leaf sheath of rice Tan-ginbozu.

\begin{tabular}{cc}
$\begin{array}{c}\text { Indoleacetic acid } \\
\mu \mathrm{g} / \text { plant }\end{array}$ & $\begin{array}{c}\text { Length of } 2 \mathrm{nd} \\
\text { leaf sheath, } \mathrm{mm}\end{array}$ \\
0 & 16.0 \\
0.1 & 15.0 \\
1 & 14.2 \\
10 & 10.6 \\
\hline
\end{tabular}

\section{ORYZA SATIVA}

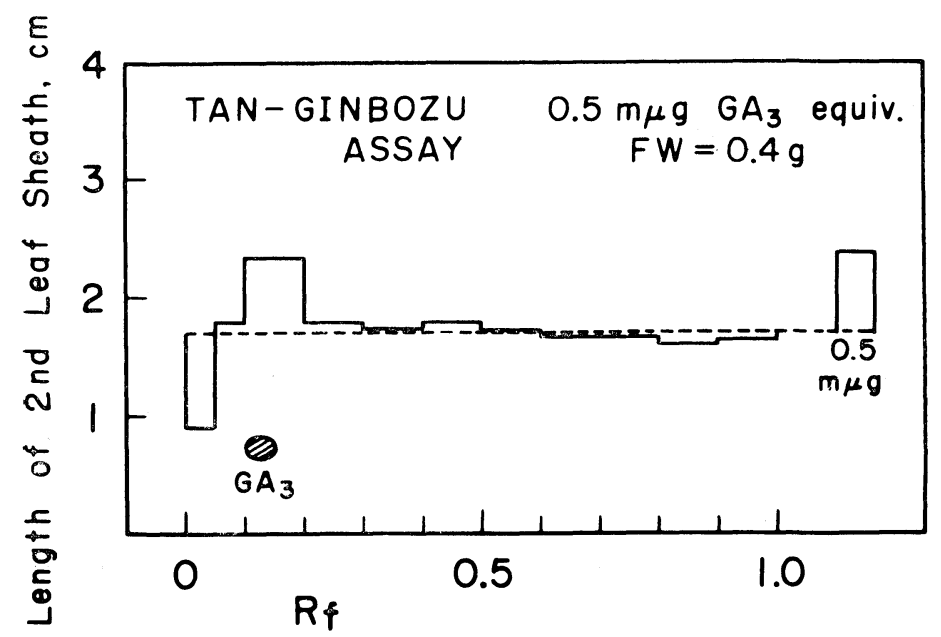

Fig. 9. Histogram showing gibberellin activity of acidic ethyl acetate fraction from rice shoots (cv. Norin 8) after TLC development with isopropyl ether: acetic acid (95:5).

A $1 \mu l$ aliquot, which was applied to each rice seedling, corresponded to the extract obtained from $0.4 \mathrm{~g}$ fresh weight of shoot material at the 5 th leaf stage. 
まり，No. 4〜No. 5 の活性物質は，矮袙Cよりも 短銀坊主に対して非常に強い活性をもったジベレ リンである.なお，この活性物質は，トウモロコシ $d_{5}$ に対する伸長促進作用が $d_{1}$ に対するよりも約 10 倍も強かった8). 最近，高橋ら ${ }^{24)}$ は，アサガオの未 熟種子から，トウモロコシ $d_{5}$ に対して活性の強い Pharbitis Gibberellin (PG) を単離し, その構造

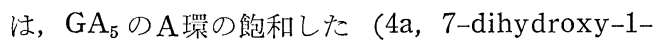
methyl-8-methylene gibb-1, $10 \beta$-dicarboxylic acid 1 $\rightarrow$ 4a-lactone) であると発表した. 高橋25)に よると， $\mathrm{GA}_{5}$ と $\mathrm{PG}$ とは，TLCで分離出来なかっ たから，第 10 図の No. 4〜No. 5 の活性は， GA あるいはPGによるものであろう.

$$
\text { むす び }
$$

植物個体の苗条伸長 促進作用に基づいたジベレ リンのバイオアッセイのらち, $\mathrm{GA}_{3}$ の絶対量からみ て最も感度の高いものは, 矮性エンドウを用いる,

\section{PHARBITIS NIL}
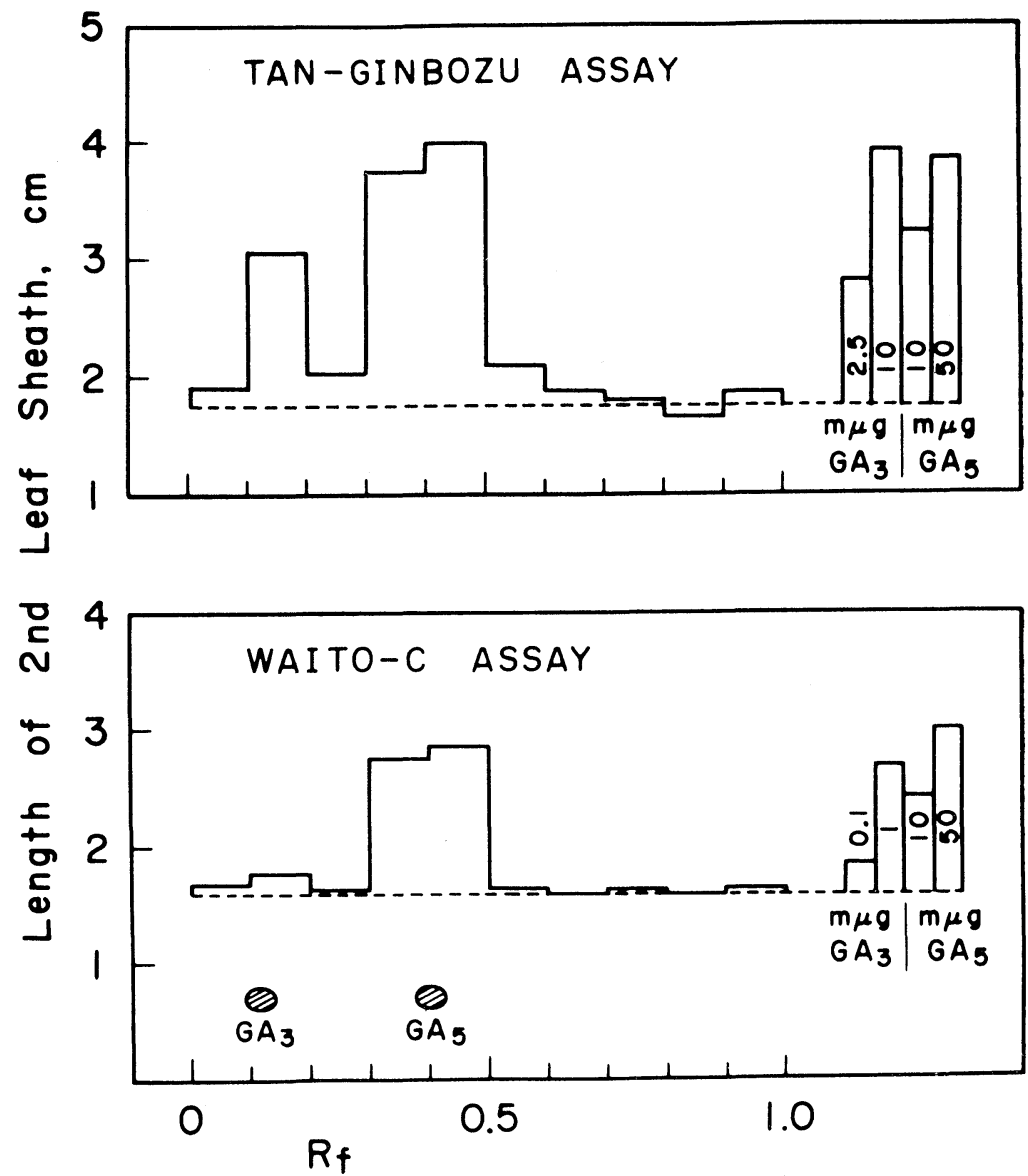

Fig. 10. Histograms showing gibberellin activity of acidic chloroform fraction from immature seeds of Pharbitis nil after TLC development with isopropyl ether: acetic acid (95:5).

A $1 \mu l$ aliquot, which was applied to each rice seedling, corresponded to the extract obtained from $10 \mathrm{mg}$ dry weight of seed material. 
Cohen ら 18)の片法や，矮性アサガオを朋いる広野 ら 26)の方法である. いずれも，約 $0.1 \mathrm{~m} \mu \mathrm{g} の \mathrm{GA}_{3}$ から榆出可能であると, 報告されている.ここに報 告した点滴法によるイネ苗テストはこれらと同程 度の $\mathrm{GA}_{3}$ 量の検讪が出来る。

また,この方法は, 次の様な利点がある。

（1）植物個体の苗条伸長促進を利用するバイ才 アッセイは，一般に，試験液で処理後，測定まで 1 週閒前後を必要とする。しかし，点㶄法によるイネ 苗テストは 2〜3 日でよい。

（2）試験液が微量で足りるから，贵重な試料の アッセイに邂している.

（3）試料が生長点に直接ふれないために，試料 中に含まれる阻害物による苗の枯死が起りにくい.

（4）試験液の代りに，寒天片を使用し，拡散性:ジ ベレリンの検出が可能である.

将来, さらに多くのジベレリンについて比活性が 測定され秃ば，イネの矮性突然变異体を利用するこ のイネ苗テストは，トウモロコシテストのように， ジベレリンの同定に役立つであろら.

\section{文}

\section{献}

1) Murakami, Y., Bot. Mag. Tokyo $70: 376$ (1957).

2) Radley, M., Ann. Bot. $22: 297$ (1958).

3) Phinney, B. O., and West, C. A., In Encyclopedia of Plant Physiol., 14. Edited by W. Ruhland. p 1188. Springer-Verlag, Berlin, (1961).

4) Morinaga, T., and Fukushima, E., Gakugei Zasshi 10: 301 (1943).

5) Murakami, Y., and Suge, H., unpublished.
6) Murakami, Y., Bot. Mag. Tokyo 79: 315 (1966).

7) MacMillan, J., and Suter, P. J., Nature, 197: 790 (1963).

8) Murakami, Y., unpublised.

9) Coombe, B. G., Cohen, D., and Paleg, L. G., Plant Physiol. 42 : 113 (1967).

10) West, C. A., and Phinney, B. O., J. Am. Chem. Soc. $81: 242$ (1959).

11) Brian, P. W., Hemming, H. G., and Lowe, D., Ann. Bot. 28 : 369 (1964).

12) Blumenthal-Goldschmidt, S., and Lang, A., Nature 186: 815 (1960).

13) Hayashi, F., Blumenthal-Goldshmidt, S., and Rappaport, L., Plant Physiol. 37: 774 (1962).

14) Butcher, D. N., J. Expt. Bot. $14: 272$ (1963).

15) Hashimoto, T., and Yamaki, T., Bot. Mag. Tokyo 73: 64 (1960).

16) Ogawa, Y., ibid. $80: 27$ (1967).

17) Jones, R. L., and Phillips, I. D. J., Nature 204: 497 (1964).

18) Cohen, D., Robinson, J. B., and Paleg, L. G., Aust. J. Biol. Sci. 19: 535 (1966).

19) Kuraishi, S., and Yamaki, T., Bot. Mag. Tokyo 77 : 199 (1964).

20) Koshimizu, K., Fukui, H., Mitsui, T., and Ogawa, Y., Agr. Biol. Chem. 30 : 941 (1966).

21) Yabuta, T., and Hayashi, T., J. Imp. Agr. Exp. Sta. 3: 365 (1940).

22) Murakami, Y., Bot. Mag. Tokyo 69: 258 (1956).

23) _- ibid. $73: 186$ (1960).

24) Takahashi, N., Murofushi, N., Yokota, T., and Tamura, S., Tetrahedron letters, No. 12, 1065 (1967).

25) Takahashi, N., Personal communication.

26) Hirono, Y., Ogawa, Y., and Imamura, S., Plant \& Cell Physiol. 1: 81 (1960). 